\title{
Assessment of Water Quality in a Border Region Between the Atlantic Forest and an Urbanised Area in Rio de Janeiro, Brazil
}

\author{
Marize Pereira Miagostovich • Flávia Ramos Guimarães • Carmen Baur Vieira • \\ Tulio Machado Fumian • Nilson Porto da Gama $\cdot$ Matias Victoria • \\ Jaqueline Mendes de Oliveira • Anna Carolina de Oliveira Mendes • \\ Ana Maria Coimbra Gaspar · José Paulo Gagliardi Leite
}

Received: 11 March 2014/ Accepted: 25 April 2014/Published online: 13 May 2014

(C) Springer Science+Business Media New York 2014

\begin{abstract}
The preservation of water resources is one of the goals of the designation of parks that act as natural reservoirs. In order to assess the impact of the presence of humans in an environmental preservation area bordering urban areas, the presence of four pathogenic enteric viruses [group A rotavirus (RV-A), norovirus (NoV), human adenoviruses (HAdV), and hepatitis A virus (HAV)], as well as the physico-chemical parameters, and Escherichia coli levels were assessed in riverine water samples. From June 2008 to May 2009, monthly monitoring was performed along the Engenho Novo River. RV-A, NoV, and HAdV were observed in $29 \%$ (31/108) of the water samples, with concentrations of up to $10^{3}$ genome copies/liter. The natural occurrence of infectious HAdV was demonstrated by Integrated Cell Culture-PCR (ICC-PCR). This study confirms the suitability of using the detection of fecal-oral transmitted viruses as a marker of human fecal contamination in water matrices and indicates the spread of pathogenic viruses occurring in an alleged area of environmental protection.
\end{abstract}

Keywords Environmental virology - Group A rotavirus . Norovirus · Human adenovirus · Hepatitis A virus · Urban forest

M. P. Miagostovich $(\bowtie) \cdot$ F. R. Guimarães ·

C. B. Vieira - T. M. Fumian - N. P. da Gama - M. Victoria

J. P. G. Leite

Laboratory of Comparative and Environmental Virology,

Oswaldo Cruz Institute, Oswaldo Cruz Foundation, 21040-360,

Avenida Brasil, Rio de Janeiro 4365, Brazil

e-mail: marizepm@ioc.fiocruz.br

J. M. de Oliveira - A. C. de Oliveira Mendes - A. M. C. Gaspar Laboratory of Technology Development in Virology, Oswaldo

Cruz Institute, Oswaldo Cruz Foundation, Rio de Janeiro, Brazil

\section{Introduction}

The Atlantic Forest biome is a tropical forest that covers the Eastern, South-eastern, and Southern regions of Brazil. Seven of the nine major river basins of the country are located in these geographic areas. Additionally, the forest supports the quantity and quality of the drinking water that supplies more than 110 million Brazilians in approximately 3,400 municipalities (http://www.ibflorestas.org.br/biomamata-atlantica.html).

The State of Rio de Janeiro (Southeast region) is fully located in the Atlantic Forest Biome. However, it is currently estimated that less than $20 \%$ of the state is covered by forest that is part of an environmental preservation area (http://www.sosma.org.br). The Pedra Branca State Park is an area located in west Rio de Janeiro and is 12,500 ha of area, making it one of the largest urban parks in the world. The geographical position of the park, which is surrounded by areas of increasing urbanization, is a conflicting factor for environmental conservation. In addition to the concentration of housings, the discharge of sewage, and soil degradation, the reduction of riparian vegetation along the basins might be responsible for the contamination of reservoirs that supply many surrounding neighborhoods (http://www.parquepedrabranca.com/p/macico-da-pedrabranca.html).

Fecal pollution is a primary health concern in the environment, with contaminated water being a potential source of gastrointestinal diseases, especially those associated with viral infections. Hepatitis is another waterrelated disease with a significant public health impact, especially in developing countries (Bosch et al. 2008; Gentile 2008).

Currently, some studies have proposed the detection of enteric viruses as an indicator of human contamination, 
Fig. 1 Satellite photo of Fiocruz, Atlantic forest campus. Red points represent the location of the collection points (Color figure online)

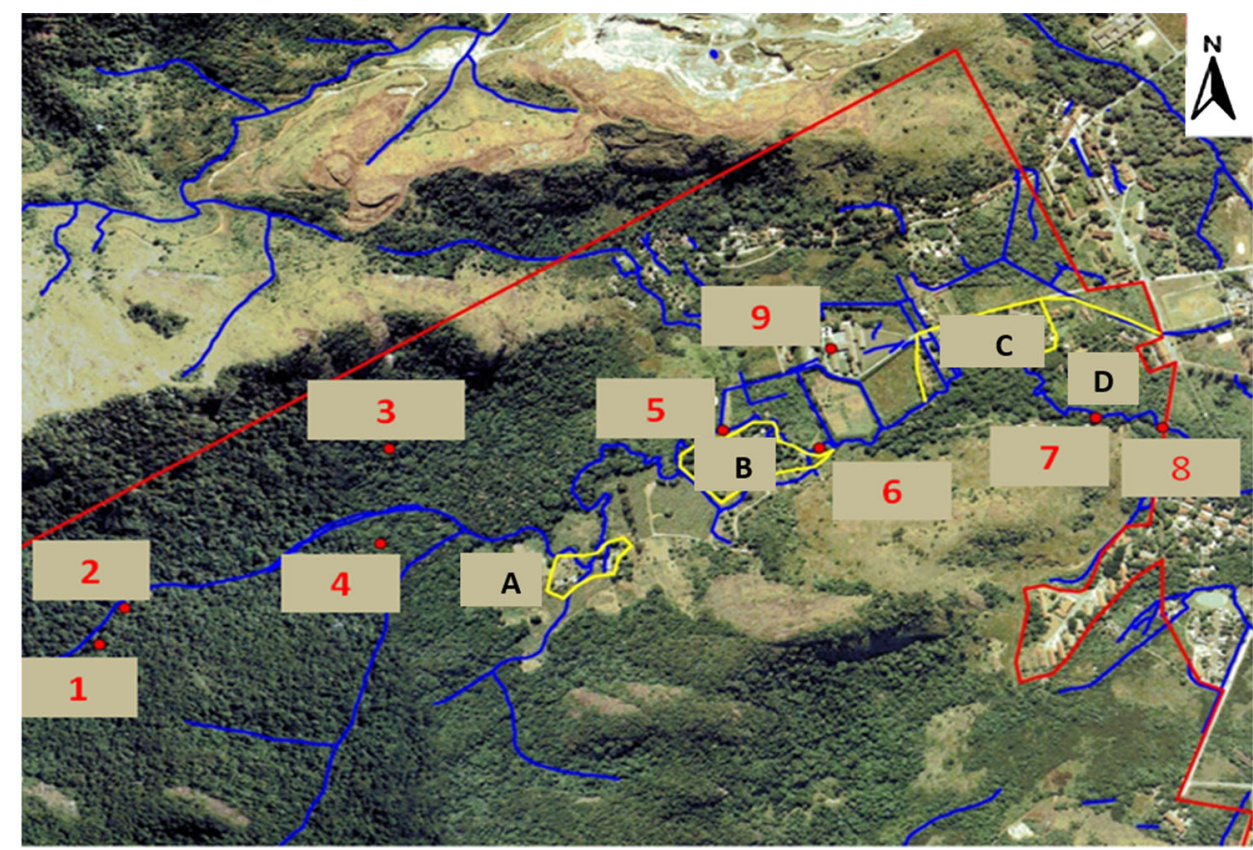

River current courses

Human settlement: A e B: Fincão; C: Sampaio; D: Viana since the lack of association between virus presence and classical bacterial markers routinely used for water quality assessment is well recognized (Pina et al. 1998, Pusch et al. 2005; Wyer et al. 2012). In this study, the presence of Escherichia coli (E. coli) and four enteric viruses [group A rotavirus (RV-A), norovirus (NoV), human adenovirus (HAdV), and hepatitis A virus (HAV)], as well as physicochemical parameters were investigated in riverine water samples in order to assess the impact of humans in an area of environmental preservation.

\section{Materials and Methods}

\section{Study Area}

Monitoring of samples was performed along the Engenho Novo River located in a unit of environmental preservation that is adjacent to and partially overlaps the Pedra Branca State Park in the Metropolitan Region of Rio de Janeiro. This bordering region contains 200 houses and approximately 1,000 residents, with many of them getting food from family farms. The whole river is used for recreational purposes.

Nine sampling collection points (P1-P9) were determined using a global positioning system (GPS, Garmin Etrex Legend $^{\circledR}$, USA). Eight of them (P1-P8) were located along the river and grouped into two sets defined by demographic characteristics. P1-P4 were located in a nonoccupied area, and P5-P8 were in an inhabited area. P9 was defined as a pickup point for river water that was piped to be used for consumption (Fig. 1).

\section{Environmental Sample Collection}

From June 2008 to May 2009, surface water samples (2 L each) were collected monthly in sterile bottles and transported to the laboratory, where they were immediately processed to investigate the presence of viruses and bacteria. Physico-chemical parameters were measured in loco. Extra samples from P3 to P8, representing points of collection from locations with different demographic characteristics, were obtained to evaluate the recovery rate of RV-A and NoV GII through spiking experiments.

\section{Physico-Chemical Parameters}

Temperature $\left({ }^{\circ} \mathrm{C}\right)$, conductivity $(\mu \mathrm{S} / \mathrm{cm})$, dissolved oxygen (DO) $(\mathrm{mg} / \mathrm{L})$, turbidity (NTU), and $\mathrm{pH}$ were measured using the Water Quality Checker ${ }^{\circledR}$ U-10 (Horiba Ltd, Kyoto, Japan). Statistical analyses were performed using GraphPad Prism ${ }^{\circledR}$ software, v 5. A Mann-Whitney U test was used to assess significant differences between values recorded from the two areas (P1-P8). A $p$ value less than 0.05 was considered to be statistically significant. 
Bacteriological Analysis

To quantify the microbial indicator $E$. coli, we used the Colilert $^{\circledR}-18$ Quanti-Tray ${ }^{\circledR} / 2000$ Kit (IDEXX Laboratories, Connecticut, USA) following the manufacturer's instructions. This method was performed within $2 \mathrm{~h}$ of collection on $10^{-1}-10^{-2}$ dilutions, and results were expressed as the Most Probable Number (MPN)/100 mL.

\section{Virus Concentration Method}

Viruses were concentrated from the $2 \mathrm{~L}$ water samples by an adsorption-elution method using a negatively charged membrane, as described by Katayama et al. (2002). Prior to the adsorption step, the residue was removed by filtration with a pre-filter AP-20 ${ }^{\circledR}$ (Millipore, Brazil). After the steps of concentration (adsorption/elution, and ultrafiltration) a final volume of $2 \mathrm{~mL}$ was obtained. For cleaning, the system was soaked briefly in a $10 \%$ solution of bleach and then rinsed in deionised water prior to each use.

The efficiency of the viral concentration method was evaluated by spiking experiments with known concentrations of RV-A [3.0 $\times 10^{8}-1.5 \times 10^{9}$ genome copies (GC)/ L] and NoV genogroup (G) II $\left(1.6 \times 10^{5}-1.6 \times 10^{6} \mathrm{GC} /\right.$ L). Samples were processed following the same method as described above. Virus recovery rates obtained from water samples collected in P3 were $6.2 \%$ and $6.7 \%$ for RV-A and NoV GII, respectively. For water samples collected from P8, recovery rates were 0.5 and $3.3 \%$ for RV-A and NoV GII, respectively.

\section{Genome Purification, Reverse Transcription, and Virus} Detection

The viral nucleic acids were extracted from the concentrated water using the QIAamp ${ }^{\circledR}$ viral RNA Mini kit (QIAGEN, Valencia, Spain) following the manufacturer's instructions. The cDNA synthesis was performed using random primer $\mathrm{pd}(\mathrm{N}) 6^{\mathrm{TM}}$ (Amersham Biosciences, USA) and the SuperScript ${ }^{\circledR}$ III Reverse Transcriptase (Invitrogen, USA). The detection of RV-A, HAdV, NoV, and HAV were performed using quantitative polymerase chain reaction (qPCR), using TaqMan ${ }^{\circledR}$ Universal PCR Master Mix kit (Applied Biosystems, CA, USA), and specific primers and probes as previously described (Heim et al. 2003; Kageyama et al. 2003, Villar et al. 2006; Zeng et al. 2008). Table 1 shows primers, probe sequences, and the target genome region of qPCR amplification. Reactions were performed in duplicate using the ABI $7500^{\circledR}$ Real-Time PCR System (Applied Biosystems). Specific positive and negative controls (positive clinical samples previously sequenced for each virus type and RNA/DNA-free water) were used in all procedures.
Integrated Cell Culture/PCR (ICC-PCR)

To assess the potential for virus infectivity, samples that were HAdV-positive by qPCR were inoculated onto HEK 293 cells (human embryonic kidney cells transformed by HAdV-5) for virus isolation. Prior to this step, cytotoxicity assays were performed according to Rigotto et al. (2010). Briefly, autoclaved water samples were tested in serial twofold dilutions in serum-free Dulbecco's MEM medium (Gibco ${ }^{\circledR}$ Invitrogen, MA, USA). The cells were analyzed to establish the noncytotoxic dilutions to be used for ICCPCR. Water sample dilutions of 1:2 and 1:4 (noncytotoxic condition) were used in HEK 293 cells when ICC-PCR was applied. For the HAdV infectivity, $200 \mu \mathrm{L}$ of each dilution selected was inoculated in duplicate in tubes containing monolayers of a HEK 293 cells $\left(10^{5}-10^{6}\right.$ cell $\left./ \mathrm{mL}\right)$ and incubated for $1 \mathrm{~h}$ at $37{ }^{\circ} \mathrm{C}$ to allow for viral adsorption. Afterward, the inoculum was removed, and the cells were washed twice with $1 \mathrm{x}$ PBS in order to remove virus particles that had not penetrated the cells. The tubes were incubated at $37{ }^{\circ} \mathrm{C}$ for $48 \mathrm{~h}$ in maintenance medium. After this period, cells were removed from the surface of the tubes and lysed by freezing/thawing $\left(-70^{\circ} \mathrm{C} / 37^{\circ} \mathrm{C}\right)$ three times to release the virus particles. The samples were then centrifuged at $5,000 \times g$ for $15 \mathrm{~min}$ at $4{ }^{\circ} \mathrm{C}$, and the supernatant was recovered for HAdV DNA purification, as described above. To confirm virus replication, a nestedPCR was performed according to the protocol described by Allard et al. (1992).

\section{Results}

A total of 108 water samples were obtained: 96 from along the Engenho Novo stream (P1-P8) and 12 from the point of water abstraction for producing tap water (P9). Physicochemical parameter analysis revealed no variation in the mean values for all of the points studied, except for turbidity, which increased significantly $(p=0.028)$ in the inhabited area of the campus (P5-P8; Table 2). Water samples from this specific area had E.coli concentrations ranging from $2.2 \times 10^{3}-1.3 \times 10^{4} \mathrm{MPN} / 100 \mathrm{~mL}$ in $98 \%(47 / 48)$ of them. P1-P4 showed values ranging from 3.0-4.0 $\times 10^{2}$ MPN/100 mL, and in P9, the values were less than $2.9 \times 10^{1}$ MPN/100 mL in all of the samples analyzed.

Concerning viral contamination, $29 \%$ (31/108) of the water samples studied had at least one virus detected, totaling 37 strains. RV-A $(n=17)$, NoV GII $(n=10)$, NoV GI $(n=3)$, and HAdV $(n=7)$ were detected at logarithmic concentrations of $10^{3}$. The HAV genome was not detected in any sample. The inhibited area (P5-P8) represented $74.2 \%$ of the virus-positive water samples, 
Table 1 Oligonucleotide primer and probe sequences and genome regions used for virus detection and quantification in water samples

a 6-Carboxyfluorescein (FAM) or 4,7,2'-trichloro-7'-phenyl-6carboxyfluorescein (VIC) used as reporter dye and was coupled to the $5^{\prime}$ end of the

oligonucleotide probe, and 6-carboxy-

tetramethylrhodamine

(TAMRA) was used as the quencher dye and was coupled at the $3^{\prime}$ end

ORF Open reading frame, $N C R$ noncoding region, and mixed bases in the primers/probes: $Y \mathrm{C} / \mathrm{T}, N \mathrm{~A} / \mathrm{T} / \mathrm{C} / \mathrm{G}, R \mathrm{~A} / \mathrm{G}$, $W \mathrm{~A} / \mathrm{T}$, and $B \mathrm{C} / \mathrm{G} / \mathrm{T}$

\begin{tabular}{|c|c|c|c|c|}
\hline Viruses & $\begin{array}{l}\text { Primers/ } \\
\text { Probe }\end{array}$ & Nucleotide sequence & $\begin{array}{l}\text { Genome } \\
\text { region }\end{array}$ & References \\
\hline \multirow[t]{3}{*}{ RV-A } & NSP3F & ACCATCTWCACRTRACCCTCTATGAG & NSP3 & \multirow{3}{*}{$\begin{array}{l}\text { Zeng et al. } \\
\quad(2008)\end{array}$} \\
\hline & NSP3R & GGTCACATAACGCCCCTATAGC & \multirow[t]{2}{*}{ Gene segment } & \\
\hline & Probe & AGTTAAAAGCTAACACTGTCAAA & & \\
\hline \multirow[t]{3}{*}{ HAdV } & AQ1 F & GCCACGGTGGGGTTTCTAAACTT & \multirow[t]{3}{*}{ Hexon gene } & \multirow{3}{*}{$\begin{array}{l}\text { Heim et al. } \\
(2003)\end{array}$} \\
\hline & AQ2 R & GCCCCAGTGGTCTTACATGCACATC & & \\
\hline & Probe $^{a}$ & TGCACCAGACCCGGGCTCAGGTACTCCGA & & \\
\hline \multirow[t]{3}{*}{$\begin{array}{r}\text { NoV } \\
\text { GI }\end{array}$} & COG1F & CGYTGGATGCGNTTYCATGA & \multirow[t]{3}{*}{$\begin{array}{l}\text { ORF1-ORF2 } \\
\text { junction }\end{array}$} & \multirow[t]{3}{*}{$\begin{array}{l}\text { Kageyama et al. } \\
\text { (2003) }\end{array}$} \\
\hline & COG1R & CTTAGACGCCATCATCATTYAC & & \\
\hline & Probe $^{\mathrm{a}}$ & AGATYGCGATCYCCTGTCCA & & \\
\hline \multirow[t]{3}{*}{$\begin{array}{l}\mathrm{NoV} \\
\text { GII }\end{array}$} & COG2F & CARGARBCNATGTTYAGRTGGATGAG & \multirow[t]{3}{*}{$\begin{array}{l}\text { ORF1-ORF2 } \\
\text { junction }\end{array}$} & \multirow[t]{3}{*}{$\begin{array}{l}\text { Kageyama et al. } \\
\text { (2003) }\end{array}$} \\
\hline & COG2R & TCGACGCCATCTTCATTCACA & & \\
\hline & Probe $^{a}$ & TGGGAGGGCGATCGCAATCT & & \\
\hline \multirow[t]{3}{*}{ HAV } & Forward & CTGCAGGTTCAGGGTTCTTAAATC & \multirow[t]{3}{*}{$5^{\prime} \mathrm{NCR}$} & \multirow{3}{*}{$\begin{array}{l}\text { Villar et al. } \\
\text { (2006) }\end{array}$} \\
\hline & Reverse & GAGAGCCCTGGAAGAAAGAAGA & & \\
\hline & Probe $^{a}$ & АCTCATTTTTCACGCTTTCTG & & \\
\hline
\end{tabular}

Table 2 Mean values of physico-chemical parameters grouped according to demographic characteristics

\begin{tabular}{llllll}
\hline $\begin{array}{l}\text { Sampling collection } \\
\text { points (no. of samples) }\end{array}$ & \multicolumn{2}{l}{ Physico-chemical parameters } & & \\
\cline { 2 - 6 } & $\mathrm{pH}$ & $\begin{array}{l}\text { Conductivity } \\
(\mathrm{mS} / \mathrm{cm})\end{array}$ & $\begin{array}{l}\text { Turbidity* } \\
(\mathrm{NTU})\end{array}$ & $\begin{array}{l}\text { Dissolved oxygen } \\
(\mathrm{mg} / \mathrm{L})\end{array}$ & $\begin{array}{l}\text { Temperature } \\
\left({ }^{\circ} \mathrm{C}\right)\end{array}$ \\
\hline P1-4 (48) & 7.0 & 0.083 & 0.3 & 8.2 & 21.6 \\
P5-8 (48) & 6.7 & 0.100 & 3.0 & 7.8 & 22.5 \\
P9 (12) & 7.0 & 0.081 & 0.8 & 7.4 & 23.5 \\
\hline
\end{tabular}

* $p<0.05$, Mann-Whitney $U$ test

$\mathrm{mS} / \mathrm{cm}$ milliSiemens per centimeters, $N T U$ nephelometric turbidity units, $\mathrm{mg} / \mathrm{L}$ milligram per liter, $C$ Celsius

Table 3 Detection of group A rotavirus (RV-A), norovirus genogroup I and II (NoV GI and GII), human adenovirus (HAdV), and hepatitis A viruses (HAV)

\begin{tabular}{llllllll}
\hline Sampling & \multirow{l}{*}{$\begin{array}{l}\text { Positive samples/ } \\
\text { collection points }\end{array}$} & \multicolumn{5}{l}{ Number of positive sample for any/each virus tested } \\
\cline { 3 - 8 } & analyzed samples & Any virus & RV-A & NoV GI & NoV GII & HuAdV & HAV \\
\hline P1-4 & $7 / 48(15 \%)$ & 7 & 5 & 0 & 0 & 2 & 0 \\
P5-8 & $23 / 48(48 \%)$ & 29 & 12 & 3 & 10 & 4 & 0 \\
P9 & $1 / 12(8 \%)$ & 1 & 0 & 0 & 0 & 1 & 0 \\
Total & $31 / 108(29 \%)$ & 37 & 7 & 3 & 10 & 7 & 0 \\
\hline
\end{tabular}

$78.4 \%(29 / 37)$ of the individual viruses detected, and $100 \%$ of the NoV-positive samples (Table 3).

The microbiological parameters (E.coli and gastroenteric viruses) revealed $\mathrm{RV}-\mathrm{A}$ and $\mathrm{HAdV}$ detection in P1P4, and in P9 where E.coli counts presented values lower than 2,000 MPN/mL (Fig. 2). According to Brazilian Legislation (BRASIL 2000), $43.5 \%$ (47/108) of environmental samples (P1-P9) were deemed inappropriate. This E.coli value is used as a cut off for classifying primary contact recreational water in the categories acceptable and unacceptable.
The cytotoxicity assay demonstrated a natural occurrence of infectious $\mathrm{HAdV}$ in two (P6-P9) of seven positive samples, as was determined by the observation of bands of the expected size (171 bp) by gel electrophoresis (data not shown).

\section{Discussion}

The main approach of this study was to demonstrate the impact of human presence in an Atlantic forest biome with 


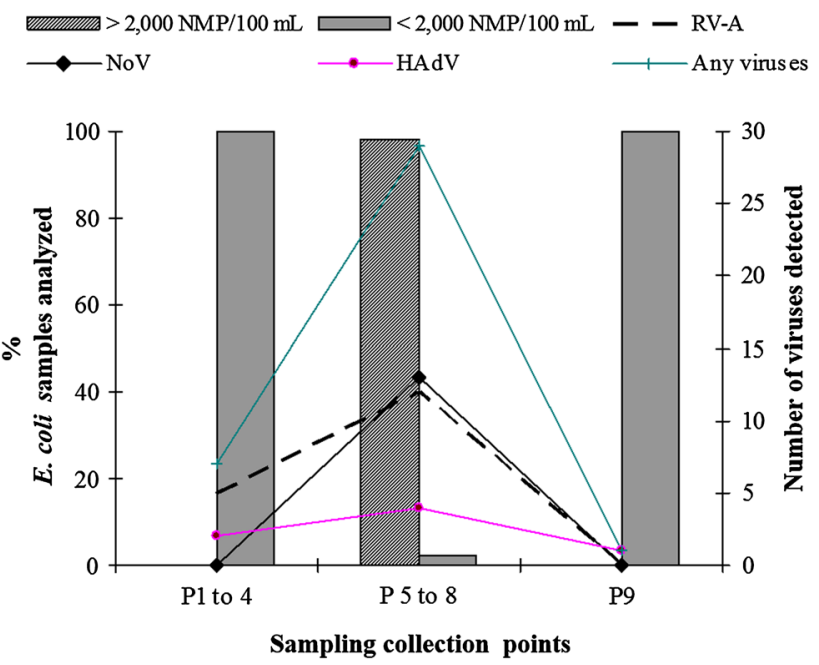

Fig. 2 Detection of rotavirus A (RV-A), norovirus genogroup I, II (NoV GI and GII), and human adenovirus (HAdV) according to E.coli parameters based on Brazilian regulation $(<2,000 \mathrm{MPN} / 100 \mathrm{~mL})$ and (> 2,000 MPN/100 mL)

fresh water resources using physico-chemical and microbiological criteria, with an emphasis on enteric viruses. Our results showed that virus detection was a useful tool for the characterization of human contamination, revealing the lack of environmental protection measures, such as a proper treatment of sewage, on a small scale.

For the physico-chemical analysis, all parameters showed similar results along the river, except for the turbidity, which showed statistically significant different values for the two areas studied (P1-P8). Here, turbidity mean values of $3 \mathrm{NTU}$ were associated with virus detection, as well as E.coli values above 2,000 MPN/100 mL were found in inhabited area P5-P8 area. The lack of a correlation among the physico-chemical, bacteriological, and virological parameters are well documented and many studies pointed out the need to consider viral parameters to assess water quality (Pina et al. 1998; Pusch et al. 2005; Rodriguez-Manzano et al. 2013).

The present study also showed a natural occurrence of infectious HAdV, as demonstrated by ICC-PCR, emphasizing that molecular methods used for virus detection should be considered even though such methods do not provide information on the infectivity of the viral particle (Haramoto et al. 2007; Hamza et al. 2009; Girones et al. 2010). In fact, the low stability of free nucleic acids in the environment suggests that molecular methods detect intact viral particles and not the particle-free viral genome (Meleg et al. 2006; Carducci et al. 2008), and ICC-PCR has been described as a useful tool, providing more reliable data regarding the infectious potential of viral particles (Rigotto et al. 2005; 2010; Dong et al. 2010). In the present study, the risk of using water for human consumption (P9) obtained from natural resources that impacted by human presence without previous treatment was demonstrated.

As previously observed by Miagostovich et al. (2008), RV-A and HAdV were detected in remote areas, where the forest and the river water have not undergone heavy anthropogenic influence. The use of the water for recreational purposes, the resistance of these viruses, the high prevalence of RV-A in Brazil (Leite et al. 2008; CarvalhoCosta et al. 2009), and the fact that all HAdV is excreted in feces (Mena and Gerba 2009) may explain their occurrence in these areas. Although HAV was not detected in this study, its presence in the Metropolitan Region of the Rio de Janeiro was demonstrated by molecular detection in $58 \%$ $(14 / 24)$ of raw sewage samples obtained from an urban wastewater treatment plant located in the city (Prado et al. 2012).

The ability to detect infectious viral particles in water and other environmental samples is of great importance in predicting public health risks (Ko et al. 2003). However, developing countries, such as Brazil, have not yet established a standard for determining the risk of viral infection from environmental water meant for consumption or recreational purposes in the current legislation. This study confirms the suitability of using the detection of enteric transmitted viruses as an alternative marker of human fecal contamination in water matrices and indicates that the spread of pathogenic viruses is occurring in an alleged area of environmental protection. The applicability of viral detection can assist studies of environmental impact assessments, helping with effective solutions for the prevention and control of water-related diseases in areas with varying degrees of human occupation and environmental disturbance.

Acknowledgments The authors would like to thank the Staff of Fiocruz, Atlantic Forest campus. The Project was financially supported by PROBIO II (0151000125). This research study is under the scope of the activities of Fiocruz as a Collaborating Center of PAHO/ WHO of Public and Environmental Health.

\section{References}

Allard, A., Albinsson, B., \& Wadell, G. (1992). Detection of adenoviruses in stools from healthy persons and patients with diarrhea by two-step polymerase chain reaction. Journal of Medical Virology, 37, 149-157.

Bosch, A., Guix, S., Sano, D., \& Pintó, R. M. (2008). New tools for the study and direct surveillance of viral pathogens in water. Current Opinion in Biotechnology, 19, 295-301.

BRASIL. (2000). National Environment Council - CONAMAResolution No 274 of 29 November 2000 defines coastal bathing water criteria for Brazilian Waters. Official Gazette, Section 1 of 25 January 2001, 170-171.

Carducci, A., Morici, P., Pizzi, F., Battistini, R., Rovini, E., \& Verani, M. (2008). Study of the viral removal efficiency in a urban 
wastewater treatment plant. Water Science and Technology, 58, 893-897.

Carvalho-Costa, F. A., Araújo, I. T., Santos de Assis, R. M., Fialho, A. M., de Assis Martins, C. M., Bóia, M. N., et al. (2009). Rotavirus genotype distribution after vaccine introduction, Rio de Janeiro, Brazil. Emerging Infectious Diseases, 15, 95-97.

Dong, Y., Kim, J., \& Lewis, G. D. (2010). Evaluation of methodology for detection of human adenoviruses in wastewater, drinking water, stream water and recreational waters. Journal of Applied Microbiology, 108, 800-809.

Gentile, A. (2008). The need for an evidence-based decision-making process with regard to control of hepatitis A. Journal of Viral Hepatitis, 15, 16-21.

Girones, R., Ferrús, M. A., Alonso, J. L., Rodriguez-Manzano, J., Calgua, B., Corrêa, A.de A., et al. (2010). Molecular detection of pathogens in water-the pros and cons of molecular techniques. Water Research, 44, 4325-4339.

Hamza, I. A., Jurzik, L., Stang, A., Sure, K., Uberla, K., \& Wilhelm, M. (2009). Detection of human viruses in rivers of a densly-populated area in Germany using a virus adsorption elution method optimized for PCR analyses. Water Research, 43, 2657-2668.

Haramoto, E., Katayama, H., Oguma, K., \& Ohgaki, S. (2007). Recovery of naked viral genomes in water by virus concentration methods. Journal of Virological Methods, 142, 169-173.

Heim, A., Ebnet, C., Harste, G., \& Pring-Akerblom, P. (2003). Rapid and quantitative detection of human adenovirus DNA by realtime PCR. Journal of Medical Virology, 70, 228-239.

Kageyama, T., Kojima, S., Shinohara, M., Uchida, K., Fukushi, S., Hoshino, F. B., et al. (2003). Broadly Reactive and Highly Sensitive Assay for Norwalk-Like Viruses Based on Real-Time Quantitative Reverse Transcription-PCR. Journal of Clinical Microbiology, 41, 1548-1557.

Katayama, H., Shimasaki, A., \& Ohgaki, S. (2002). Development of a virus concentration method and its application to detection of enterovirus and norwalk virus from coastal seawater. Applied and Environmental Microbiology, 68, 1033-1039.

Ko, G., Cromeans, T. L., \& Sobsey, M. D. (2003). Detection of infectious adenovirus in cell culture by mRNA reverse transcription-PCR. Applied and Environmental Microbiology, 69, 7377-7384.

Leite, J. P., Carvalho-Costa, F. A., \& Linhares, A. C. (2008). Group A rotavirus genotypes and the ongoing Brazilian experience: a review. Memórias do Instituto Oswaldo Cruz, 103, 745-753.

Meleg, E., Jakab, F., Kocsis, B., Bányai, K., Melegh, B., \& Szucs, G. (2006). Human astroviruses in raw sewage samples in Hungary. Journal of Applied Microbiology, 101, 1123-1129.
Mena, K. D., \& Gerba, C. P. (2009). Waterborne adenovirus. Reviews of Environmental Contamination and Toxicology, 198, 133-167.

Miagostovich, M. P., Ferreira, F. F. M., Guimaraes, F. R., Fumian, T. M., Diniz-Mendes, L., Luz, S. L. B., et al. (2008). Molecular detection and characterization of gastroenteritis viruses occurring naturally in the stream waters of manaus, Central Amazonia, Brazil. Applied and Environmental Microbiology, 74, 375-382.

Pina, S., Puig, M., Lucena, F., Jofre, J., \& Girones, R. (1998). Viral pollution in the environment and in shellfish: human 11 adenovirus detection by PCR as an index of human viruses. Applied and Environmental Microbiology, 64, 3376-3382.

Prado, T., Fumian, T. M., Miagostovich, M. P., \& Gaspar, A. M. (2012). Monitoring the hepatitis a virus in urban wastewater from Rio de Janeiro, Brazil. Transactions of the Royal Society of Tropical Medicine and Hygiene, 106, 104-109.

Pusch, D., Oh, D. Y., Wolf, S., Dumke, R., Schroter-Bobsin, U., Hohne, M., et al. (2005). Detection of enteric viruses and bacterial indicators in German environmental waters. Archives of Virology, 150, 929-947.

Rigotto, C., Sincero, T. C., Simões, C. M., \& Barardi, C. R. (2005). Detection of adenoviruses in shellfish by means of conventionalPCR, nested-PCR, and integrated cell culture PCR (ICC/PCR). Water Research, 39, 297-304.

Rigotto, C., Victoria, M., Moresco, V., Kolesnikovas, C. K., Corrêa, A. A., Souza, D. S., et al. (2010). Assessment of adenovirus, hepatitis A virus and rotavirus presence in environmental samples in Florianopolis, South Brazil. Journal of Applied Microbiology, 109, 1979-1987.

Rodriguez-Manzano, J., Hundesa, A., Calgua, B., Carratala, A., Maluquer de Motes, C., Rusiñol, M., Moresco, V., Ramos, A.P., Martínez-Marca, F., et al. (2013). Adenovirus and norovirus contaminants in commercially distributed shellfish. Food and Environmental Virology, 29.

Villar, L. M., De Paula, V. S., Diniz-Mendes, L., Lampe, E., \& Gaspar, A. M. (2006). Evaluation of methods used to concentrate and detect hepatitis A virus in water samples. Journal of Virological Methods, 137, 169-176.

Wyer, M. D., Wyn-Jones, A. P., Kay, D., Au-Yeung, H. K., Gironés, R., López-Pila, J., et al. (2012). Relationships between human adenoviruses and faecal indicator organisms in European recreational waters. Water Research, 46, 4130-4141.

Zeng, S. Q., Halkosalo, A., Salminen, M., Szakal, E. D., Puustinen, L., \& Vesikari, T. (2008). One-step quantitative RT-PCR for the detection of rotavirus in acute gastroenteritis. Journal of Virological Methods, 153, 238-240. 